\title{
Comparison of measurements of peroxyacyl nitrates and primary carbonaceous aerosol concentrations in Mexico City determined in 1997 and 2003
}

\author{
N. A. Marley ${ }^{1}$, J. S. Gaffney ${ }^{1}$, R. Ramos-Villegas ${ }^{2}$, and B. Cárdenas González ${ }^{3}$ \\ ${ }^{1}$ Chemistry Department, University of Arkansas at Little Rock, Little Rock, Arkansas, USA \\ ${ }^{2}$ Secretariat of the Environment, Government of the Federal District, Mexico City, D.F., Mexico \\ ${ }^{3}$ El Centro National de Investigation y Capitación Ambiental, Instituto National de Ecologia, Secretaria de Medio Ambiente y \\ Recursos Naturales, Mexico City, D.F., Mexico
}

Received: 18 December 2006 - Published in Atmos. Chem. Phys. Discuss.: 29 January 2007

Revised: 13 April 2007 - Accepted: 15 April 2007 - Published: 4 May 2007

\begin{abstract}
The concentrations of peroxyacetyl nitrate (PAN) in ambient air can be a good indicator of air quality and the effectiveness of control strategies for reducing ozone levels in urban areas. As PAN is formed by the oxidation of reactive hydrocarbons in the presence of nitrogen dioxide $\left(\mathrm{NO}_{2}\right)$, it is a direct measure of the peroxyacyl radical levels produced from reactive organic emissions in the urban air shed. Carbon soot, known as black carbon (BC) or elemental carbon (EC), is a primary atmospheric aerosol species and is a good indicator of the levels of combustion emissions, particularly from diesel engines, in major cities. Mexico City is the second largest megacity in the world and has long suffered from poor air quality. Reported here are atmospheric measurements of PAN and BC obtained in Mexico City during the Mexico Megacity 2003 field study. These results are compared with measurements obtained earlier during the Investigación sobre Materia Particulada y Deterioro Atmosférico - Aerosol and Visibility Research (IMADA-AVER) campaign in 1997 to obtain an estimate of the changes in emissions in Mexico City and the effectiveness of control strategies adopted during that time. Concentrations of PAN in 1997 reached a maximum of $34 \mathrm{ppb}$ with an average daily maximum of $15 \mathrm{ppb}$. The PAN levels recorded in 2003 were quite different, with an average daily maximum of $3 \mathrm{ppb}$. This dramatic reduction in PAN levels observed in 2003 indicate that reactive hydrocarbon emissions have been reduced in the city due to controls on olefins in liquefied petroleum gas (LPG) and also due to the significant number of newer vehicles with catalytic converters that have replaced older higher emission vehicles. In contrast, black/elemental carbon levels were similar in 1997 and 2003 indicating little improvement likely due to the lack of controls on diesel vehicles in the city. Thus,
\end{abstract}

Correspondence to: J. S. Gaffney

(jsgaffney@ualr.edu) while air quality and ozone production have improved, Mexico City and other megacities continue to be a major source of black carbon aerosols, which can be an important species in determining regional radiative balance and climate.

\section{Introduction}

Megacities are large urban and suburban complexes whose populations are in the tens of millions of inhabitants (Lynn, 1999). With the rapid growth of the world's population and the continuing industrialization and migration of the populace towards major urban centers, the numbers of these megacities are increasing. Although New York City was the only megacity in the world in 1950, they now number 14 and their distribution is growing most rapidly in the tropical areas of South America and Asia. Today, the largest metropolitan complexes are centered at Tokyo, Japan, and Mexico City, Mexico (Molina and Molina, 2002a). Within the next 10 to 15 years it is predicted that there will be more than 30 megacities worldwide.

Megacities have become important global sources of air pollutants from the associated mobile and stationary sources and the emissions from megacities are leading to regional and global increases in many key trace gases as well as primary and secondary aerosols. The Mexico City metropolitan area (MCMA), which occupies $\sim 1300 \mathrm{~km}^{2}$ with a population of $\sim 18 \mathrm{M}$, is one of the largest megacities in the world and is well known for its high levels of air pollution and visibility reduction (Molina and Molina, 2002b). It has been estimated that emissions from the Mexico City basin contribute 15 Mega-tons of fine aerosol $\left(\mathrm{PM}_{2.5}\right)$ per year to the surrounding regions (Gaffney et al., 1999). This fine aerosol is composed of approximately $32 \%$ organic carbon, $15 \%$ elemental

Published by Copernicus GmbH on behalf of the European Geosciences Union. 
carbon, $10 \%$ ammonium nitrate and $20 \%$ ammonium sulfate (Chow et al., 2002). The emissions of sulfate aerosols alone from the MCMA are estimated to amount to $1 \%$ of the total global burden (Barth and Church, 1999). While sulfate is an important light scattering aerosol species, black carbon is an important light absorbing aerosol species. The aerosol emissions from megacities such as Mexico City therefore play potentially important roles in regional radiative balance and climate (Jacobson, 2002; Gaffney and Marley, 2005).

Elevated levels of ozone have been known for some time in Mexico City (Bravo et al., 1989; MARI, 1994; Streit and Guzman, 1996; Fast and Zhong, 1998). Mexico City is located at an altitude of $7200 \mathrm{ft}$ in an air basin surrounded by mountains (Fast and Zhong, 1998; Doran et al., 1998) and at a latitude of $19^{\circ}$ of North, which implies high levels of incoming solar radiation all year long. In the past, peak ozone levels exceeding $300 \mathrm{ppb}$ were not uncommon, particularly during the late dry winter months of February and March (The one-hour standard is $0.11 \mathrm{ppm}$ (Molina and Molina, 2002a)). These very high levels of ozone require high levels of reactive hydrocarbons as well as elevated levels of nitrogen oxide (NO) emissions to produce the coupled $\mathrm{OH}$ and peroxyradical chemistry that is key to the formation of urban ozone (Finlayson-Pitts and Pitts, 2000). Hydrocarbon measurements taken in Mexico City (Blake and Rowland, 1995) showed that the heavy domestic and commercial use of LPG has led to very high levels of butane and propane in that megacity's air, exceeding parts-per-million (ppm) of carbon in many cases. Indeed, LPG was proposed as an important source of the reactive volatile organic carbon compounds (VOCs) propene and butenes, which could account for an appreciable portion of the observed urban ozone in Mexico City (Blake and Rowland, 1995). Volatile organic carbon samples collected before and during a Mexican national holiday with reduced automobile traffic clearly showed that mobile emissions are equally important as LPG as sources of reactive olefins such as the butenes (Gaffney et al., 1999). In addition, earlier work suggested that mobile sources contribute $75 \%$ of the total hydrocarbons to the Mexico City air (Riveros et al., 1998) and that $\mathrm{NO}_{2}$ was probably the most important contributor to ozone production in Mexico City (Raga et al., 2001a).

Peroxyacyl nitrates (PANs) are important indicator compounds of peroxyradical activity in an urban air shed (Finlayson-Pitts and Pitts, 2000; Gaffney et al., 1989). Formed by the reaction of peroxyacyl radicals with $\mathrm{NO}_{2}$, they exist in equilibrium with the peroxy radical species according to:

$\mathrm{RC}=\mathrm{O}-\mathrm{O}_{2}+\mathrm{NO}_{2} \rightarrow \mathrm{RC}=\mathrm{O}-\mathrm{O}-\mathrm{O}-\mathrm{NO}_{2}$

where $\mathrm{R}$ is typically (in order of importance); $\mathrm{CH}_{3}$ - (peroxyacetyl nitrate, $\mathrm{PAN}$ ), $\mathrm{CH}_{3} \mathrm{CH}_{2}$ - (peroxypropionyl nitrate, PPN), and $\mathrm{CH}_{3} \mathrm{CH}_{2} \mathrm{CH}_{2}$ - (peroxybutryl nitrate, $\mathrm{PBN}$ ) in an urban environment. The peroxyacyl radicals are formed from the reactive olefins directly or via formation of aldehydes that can react with $\mathrm{OH}$ to form the peroxyacyl species. While the
PANs are thermally labile, the reverse reaction to reform the PANs is relatively fast leading to no net loss at elevated temperatures in areas of high $\mathrm{NO}_{2}$ concentrations (FinlaysonPitts and Pitts, 2000; Gaffney et al., 1989).

Thus, measurements of the temporal variability of the PANs are useful in determining the oxidative reactions involved in the formation of ozone as well as other secondary air pollutants and aerosol species such as nitric acid and ammonium nitrate as they are a direct measure of the peroxyacyl radical formation activity. The PANs therefore serve as a measure of the peroxy radical concentrations in the atmosphere. Since the PANs have low aqueous solubilities, low reactivity with $\mathrm{OH}$, and are slow to photolyze, they can lead to the transport of $\mathrm{NO}_{2}$ over long distances and can simultaneously act as a reservoir for $\mathrm{NO}_{2}$ during transport of the urban plume. This can have regional scale impacts on ozone, nitrate aerosols, and other pollutants associated with megacity plumes (Gaffney et al., 1989).

Carbonaceous particulate matter or "soot" particles are produced from the partial combustion of hydrocarbons, particularly from diesel fuels, and are therefore a measure of the combustion emissions in an urban area. Although the elemental composition of these particles is dominated by carbon (>90\%), soot particles may be regarded as a complex organic polymer, rather than an amorphous form of elemental carbon (Andreae and Gelencser, 2006). The absolute identification of carbon soot is difficult and the techniques commonly used, such as Raman spectroscopy, electron microscopy, and mass spectrometry are impractical for routine monitoring of this material. Various measurement methods have been developed for the routine quantitation of aerosol soot content that make use of some of its characteristic properties. These methods have created operational definitions such as "black carbon" or "elemental carbon" depending on the key property being measured (Gaffney and Marley, 2006). The term "black carbon" arises from the use of optical attenuation methods and refers to the highly absorbing nature of carbon soot aerosols. In contrast, the term "elemental carbon" is used when thermal combustion methods are employed for detection and refers to the refractory nature of the aerosols at temperatures up to $350-400^{\circ} \mathrm{C}$. Comparisons between the optical and thermal combustion methods in different environments have yielded correlation coefficients of 0.99 (Hansen and McMurry, 1990), 0.97 (Allen et al., 1999), and 0.94 (Babich et al., 2000) and the various terms used to identify combustion derived aerosols are commonly used interchangeably.

Although originally identified as a pollutant and a tracer for combustion emissions, carbon soot has more recently gained attention as a major light absorbing species with significant impacts on the radiative balance of the atmosphere (Ramanathan et al., 2005). Some model calculations suggest that the contribution of carbon soot aerosols to global warming may be as much as $0.3-0.4^{\circ} \mathrm{C}$, rivaling the contributions from atmospheric methane (Jacobson, 2004; Chung and 
Seinfeld, 2005). The ultimate climate effects from carbon aerosols will depend on their physical and chemical properties, as well as their residence times and distributions in the atmosphere (Jacobson, 2001). In order to adequately assess the aerosol impacts on global and regional climate, a better understanding of black carbon aerosol emission rates and atmospheric distributions will be essential.

In an attempt to better understand the Mexico City air chemistry with regard to oxidants and aerosols, a comprehensive collaborative study was carried out during FebruaryMarch 1997 that included a wide variety of chemistry, aerosol and meteorological measurements (Edgerton et al., 1999; Doran et al., 1998; Fast and Zhong, 1998). This field campaign (IMADA-AVER) was jointly sponsored by the U.S. Department of Energy's Office of Biological and Environmental Research Atmospheric Science Program (DOE/ASP) and Petrleos Mexicanos (PEMEX) through the Mexican Petroleum Institute (Instituto Mexicano de Petroleo, or IMP).

As part of IMADA-AVER, measurements of near-surface tropospheric PANs were made at the IMP laboratories to determine the concentrations and temporal variability of these species in the megacity (Gaffney et al., 1999). Levels of the PANs were found to approach $40 \mathrm{ppb}$ in the central metropolitan area. Peroxyacetyl nitrate was the major species, although PPN and PBN were also observed in the low ppb ranges. These are the highest values of the PANs seen in any urban area since $50 \mathrm{ppb}$ values were reported for PAN in the late 1970s downwind of Los Angeles in the south coast air basin in southern California (Tuazon et al., 1981). Volatile organic carbon measurements obtained at IMP during the same time indicated that automobiles were responsible for much of the reactive hydrocarbons in the atmosphere (Gaffney et al., 1999). The meteorological measurements demonstrated that the air basin was subject to a strong advection of the boundary layer in the afternoon leading to a clearing out of the pollutants emitted and formed during the day. This regional meteorology leads to very little carryover of the pollutants in Mexico City from day to day and atmospheric chemistry that is dominated by reactions that took place typically over a one day period (Gaffney et al., 1999; Fast and Zhong, 1998; Doran et al., 1998). The application of a simple box model indicated that considerable amounts of air pollutants, both oxidants and aerosols, were being transported out of the Mexico City air basin (Gaffney et al., 1999; Elliott et al., 1997).

In April 2003, the DOE/ASP again conducted a field study in Mexico City (Mexico Megacity 2003) in collaboration with the MCMA 2003 air quality study organized by M. J. Molina and L. T. Molina of the Massachusetts Institute of Technology. Continuous measurements of the PANs and black carbon aerosols were obtained during April 2003 at the National Center for Environmental Research and Training (Centro Nacional de Investigación y Capacitación Ambiental, or CENICA), on the Iztapalapa campus of the Uni- versidad Autónoma Metropolitana (UAM). Data were collected before and during the Easter holiday to assess changes in PAN and BC loadings as a function of vehicle traffic levels.

Results are presented here for PAN and BC concentrations obtained in Mexico City during the Mexico Megacity 2003 field study. These results are compared with those obtained 6 years earlier during the IMADA-AVER study. Changes in PAN and carbonaceous aerosol levels are presented as an indication of changes in emission levels during that time and the effectiveness of ozone control strategies that have been adopted in Mexico City since 1997. The black carbon aerosol comparisons are of particular importance in the evaluation of the regional impacts of the changing megacity emissions of this key absorbing aerosol species and its importance for regional climate considerations.

\section{Experimental methods}

Measurements were obtained from February 20 to March 23, 1997 at Building No. 24 (Refinación y Petroquimica) of the IMP laboratories (Eje Central Lazaro Cardenas No. 152, Delegacion Gustavo A. Madero, México, Districto Federale). This site is located in the north central part of Mexico City $\left(19^{\circ} 29^{\prime} 19.392^{\prime \prime} \mathrm{N}, 99^{\circ} 08^{\prime} 50.258^{\prime \prime} \mathrm{W}\right)$. The PANs were determined using an automated gas chromatograph equipped with an electron capture detection system (GC/ECD). This system has been described in detail elsewhere (Gaffney et al., 1993, 1997, 1998, 1999). A 2-cm ${ }^{3}$ sample was injected automatically onto a packed GC carbowax 400 column every $30 \mathrm{~min}$. Data were collected using a recording integrator and processed manually for each of 1380 samples. Calibration of the instrument for the PANs was accomplished by manual injection of standards synthesized by strong acid nitration of the corresponding peracids (Gaffney et al., 1984; Gaffney and Marley, 2005a).

Data for ozone and $\mathrm{NO}_{2}$ concentrations were obtained from the IMP monitoring station of the Mexico City ambient air monitoring network (la Red Automática de Monitoreo Atmosférico, or RAMA), operated at that time by the Dirección General de Prevencin y Control de la Contaminacin de la Ciudad de México. Nineteen of the 33 urban RAMA stations measure ozone by UV absorption and nitrogen oxide (NO) and total nitrogen oxides $\left(\mathrm{NO}_{\mathrm{x}}\right)$ by chemiluminescence among other criteria pollutants, which are reported as hourly averages. As the chemiluminescent nitrogen oxides analyzer in the $\mathrm{NO}_{\mathrm{x}}$ mode measures the sum of $\mathrm{NO}_{2}, \mathrm{NO}$ and PAN concentrations, the $1997 \mathrm{NO}_{2}$ concentrations were estimated by subtraction of the $\mathrm{NO}$ and PAN concentrations from $\mathrm{NO}_{\mathrm{x}}$ results $\left(\mathrm{NO}_{2} \approx \mathrm{NO}_{\mathrm{x}}-\mathrm{NO}-\mathrm{PAN}\right)$.

Measurements of the PANs, $\mathrm{NO}_{2}$ and fine aerosol black carbon content were obtained from 3 April to 1 May 2003 on the rooftop of the CENICA laboratory building (19 $21^{\prime} 44.541^{\prime \prime} \mathrm{N}, 99^{\circ} 04^{\prime} 16.425^{\prime \prime} \mathrm{W}$ ) on the UAM Iztapalapa 

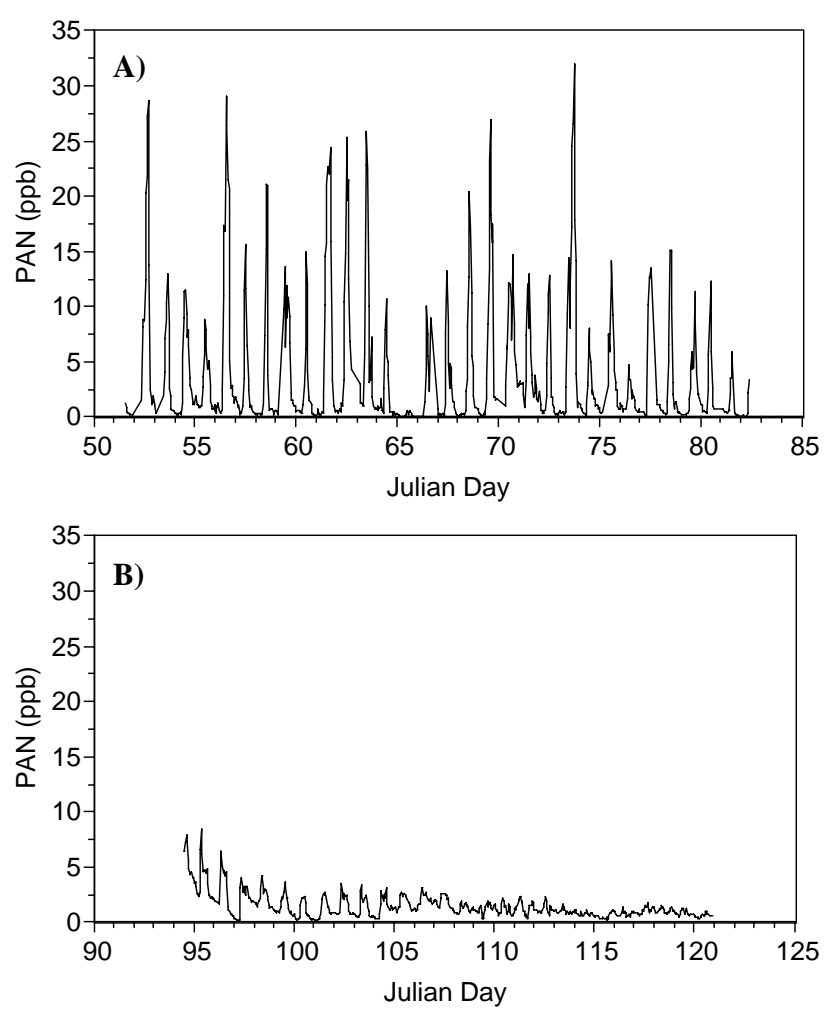

Fig. 1. (A) Concentration profiles for peroxyacetyl nitrate (PAN) measured in Mexico City from 20 February to 23 March 1997 and (B) from 3 March to 1 April 2003.

campus (Calle "Sur 10" No. 230, Colonia La Vicentina, Delegación Iztapalapa, México, D.F.). This site is approximately $16.1 \mathrm{~km}(10.0 \mathrm{mi})$ south-southwest of the site at the IMP site that was used in 1997. Measurements of the PANs and $\mathrm{NO}_{2}$ were obtained by fast gas chromatography with luminol detection. This system has been described in detail elsewhere (Marley, et al., 2004) but will be briefly reviewed here. A $2-\mathrm{cm}^{3}$ sample loop was used to automatically inject samples onto a 30-ft. capillary DB-1 column at 1-min intervals. Both $\mathrm{NO}_{2}$ and PAN were detected by the chemiluminescent reaction with luminol and the intensity of the emission at $425 \mathrm{~nm}$ was measured with a photon counting module. The instrument was controlled by a $1.8-\mathrm{GHz}$ Notebook computer with a Windows 2000 operating system and a custom software application programmed in LabVIEW. The instrument was calibrated for $\mathrm{NO}_{2}$ by dilution of a 2.8-ppm $\mathrm{NO}_{2}$ tank standard in air with a gas calibrator (Dasibi; Model 1009-CP) and for the PANs with the synthetic standards described above. This instrument has been compared with the GC/ECD method in previous studies and found to give good agreement both in field studies and with synthetic PAN standards (Gaffney et al., 1998, 2005a; Marley et al., 2004).

The black carbon content of fine aerosols was measured by using a seven-channel aethalometer (Andersen) with a sam- ple inlet designed to collect aerosols in the 0.1 to 2 micron size range. The aerosols in the air sample are collected within the instrument by continuous filtration through a paper tape strip. The optical transmission of the deposited aerosol particles is then measured sequentially at seven wavelengths (370, 450, 520, 590, 660, 880, and $950 \mathrm{~nm}$ ). Since black carbon is a strongly absorbing aerosol species with an absorption coefficient relatively constant over a broad spectral region (Marley et al., 2001) the instrument can automatically calculate the black carbon content from the transmission measurements by assuming black carbon to be the main absorbing aerosol species in the samples with a $1 / \lambda$ dependence typical of broadband absorbers and a mass specific absorption coefficient of $16.6 \mathrm{~m}^{2} / \mathrm{g}$ at $880 \mathrm{~nm}$ (Hansen et al., 1982). The instrument is operated by an embedded computer with a display screen and keypad that controls all instrument functions and automatically records the data to a built-in $3.5^{\prime \prime}$ floppy diskette. Data were recorded for each of the seven channels at a two-minute time resolution. In addition, the analog output of the $520 \mathrm{~nm}$ channel was monitored continuously and one minute averages of this channel were recorded separately.

Measurements of total $\mathrm{PM}_{2.5}$ mass concentrations were also obtained at the CENICA site by a Tapered Element Oscillating Microbalance (TEOM, Ruppert \& Pastashnick) operated at $35^{\circ} \mathrm{C}$. This instrument measures the total fine aerosol mass concentration by using a vibrating element whose frequency is dependent on the particle mass collected on a filter located at the end of the element (Hinds, 1999). Hourly averages of ozone for this time period were obtained from the RAMA station at Cerro de la Estrella (Calzada San Lorenzo, Colonia Paraje San Juan, Delegación Iztapalapa, México D.F.). This site $\left(19^{\circ} 20^{\prime} 09.184^{\prime \prime} \mathrm{N}, 99^{\circ} 04^{\prime}\right.$ $\left.28.829^{\prime \prime} \mathrm{W}\right)$ is located $3.0 \mathrm{~km}(1.8 \mathrm{mi})$ from the main sampling site at CENICA.

\section{Results and discussion}

The 30-min concentrations of PAN measured in 1997 are shown in Fig. 1a. The strong diurnal concentration pattern observed is evidence of the regional afternoon clearing of the pollutants from the MCMA basin (see Fig. 3 for expansion of diurnal detail). The PAN concentrations reached a maximum of $34 \mathrm{ppb}$ with an average daily maximum of $15 \mathrm{ppb}$. The higher PAN analogs were also observed in 1997. Levels of PPN and PBN reached 5 and 1.1 ppb respectively, giving a total maximum concentration for all the PANs of $40 \mathrm{ppb}$, the highest reported since measurements taken near Los Angeles in the 1970s (Tuazon et al., 1981). Figure 1b shows the time sequence observed for PAN in Mexico City in 2003. The PAN levels recorded in 2003 were quite different, reaching a maximum of only $8 \mathrm{ppb}$ early in the study with an average daily maximum for the time period of $3 \mathrm{ppb}$. In addition, neither PPN nor PBN were observed above the detection limit 

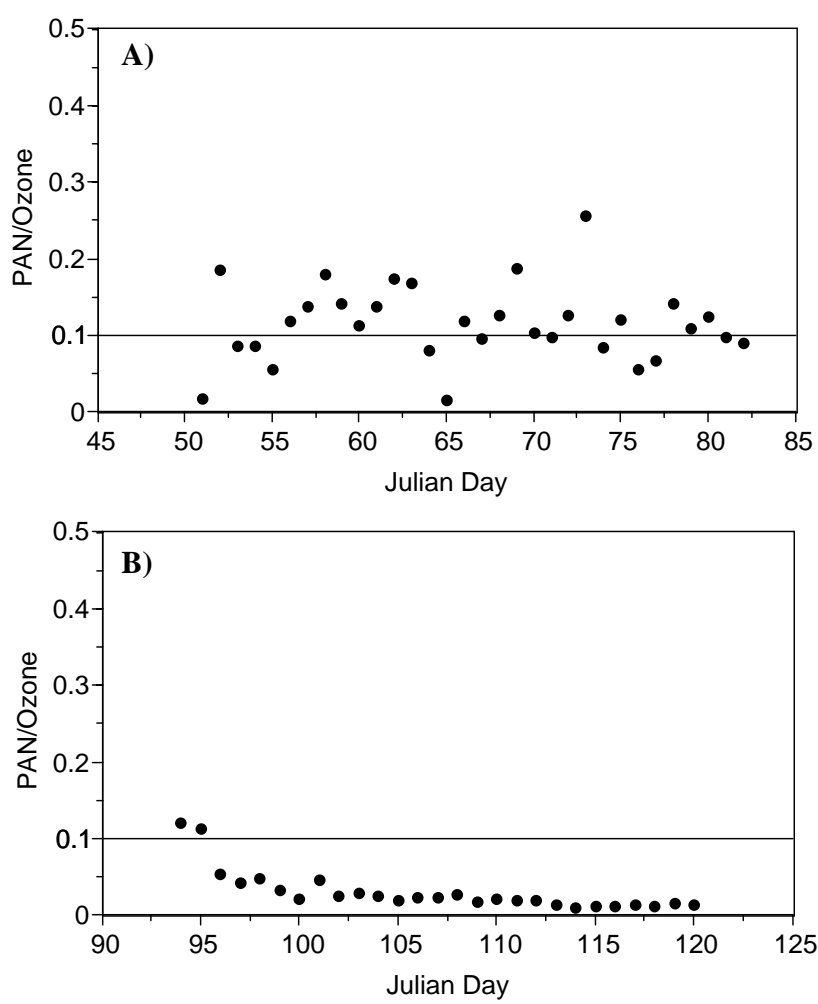

Fig. 2. (A) The ratio of PAN to Ozone daily maximum concentrations in Mexico City from 20 February to 23 March 1997 and (B) from 3 March to 1 April 2003.

of $0.02 \mathrm{ppb}$ at any time during the 2003 study period. The typical diurnal concentration pattern is evident in the first 14 days of the study, indicating the same daily meteorological patterns observed in 1997 leading to a daily clearing of the basin.

18 April 2003 (Julian day 108) was Good Friday marking the beginning of the holiday period accompanied with a decrease in traffic levels and a decrease in mobile and stationary emissions. Average carbon monoxide concentrations dropped by a factor of 2 and peak concentrations dropped by a factor of 4 from the levels reported on the previous Friday. This resulted in even lower PAN levels after that day. The average daily maximum before 18 April was $4 \mathrm{ppb}$ while the average daily maximum afterwards was $1.7 \mathrm{ppb}$. The IMADA-AVER study in 1997 also incorporated a Mexican national holiday (Benito Juarez's Birthday) on 21 March (Julian Day 80). The maximum PAN concentration observed on that day was $12 \mathrm{ppb}$.

The hourly average ozone concentrations reached a maximum of $242 \mathrm{ppb}$ during the 1997 study period but only reached $135 \mathrm{ppb}$ in 2003. The ratio of PAN to ozone daily maximum hourly average concentrations is shown in Fig. 2a for 1997 and Fig. 2b for 2003. Past measurements of PAN and ozone concentration in polluted air masses have yielded a ratio of 0.1 (Tuazon et al., 1981; Finlayson-Pitts and
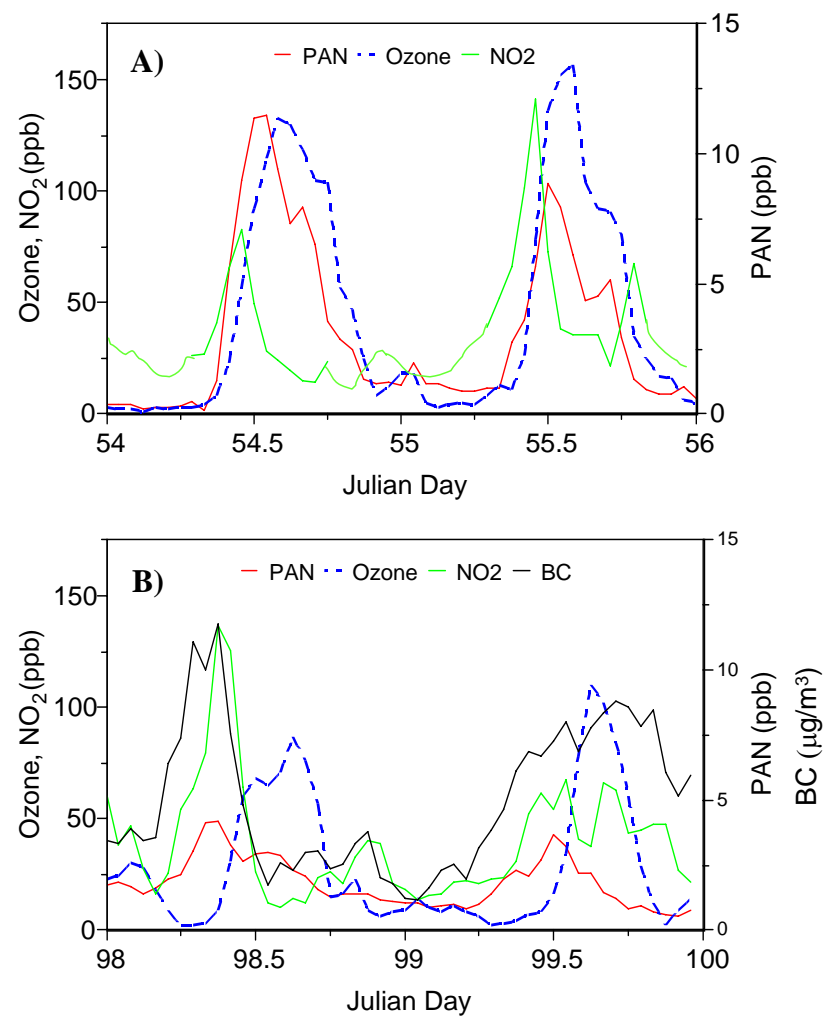

Fig. 3. (A) Concentration profiles for ozone, $\mathrm{NO}_{2}$, and PAN, for Julian Day 55 and 56, 1977 and (B) for ozone, $\mathrm{NO}_{2}, \mathrm{PAN}$, and black carbon aerosols for Julian Day 98 and 99, 2003.

Pitts, 2000; Gaffney et al., 1989). The observed ratio of PAN/ozone in 1997 generally agrees with the value of 0.1 . However, many days exceeded 0.1 and 6 out of the 32 study days exceeded a ratio of 0.2 . This has been attributed to the significant presence of PAN precursors, including higher aldehydes and olefins, in the Mexico City air during that time and also to the fact than the higher PAN levels act to tie up $\mathrm{NO}_{2}$ thus reducing the ozone production rate and the subsequent atmospheric ozone levels (Gaffney et al, 1999). The PAN/ozone values observed in 2003 only reached the value of 0.1 the first two days of the study. The PAN/ozone ratios after 5 April (Julian Day 95) were significantly below 0.1 with an average daily value of 0.02 for the rest of the study period and an average of 0.03 for the period before the Easter holiday.

As expected, $\mathrm{NO}_{2}$ levels were also lower in 2003 than in 1997. The maximum $\mathrm{NO}_{2}$ concentrations reached $205 \mathrm{ppb}$ in 1997 and $137 \mathrm{ppb}$ in 2003. Figure 3a shows the concentration profiles of ozone, $\mathrm{NO}_{2}$, and PAN for two representative days in 1997. Figure 3b shows similar concentration profiles for 2003. Although the overall concentration levels are lower in 2003 than in 1997, the concentration profiles appear to follow similar patterns. There is a rapid conversion of $\mathrm{NO}$ to $\mathrm{NO}_{2}$ in the Mexico City air in both 1997 and 2003 

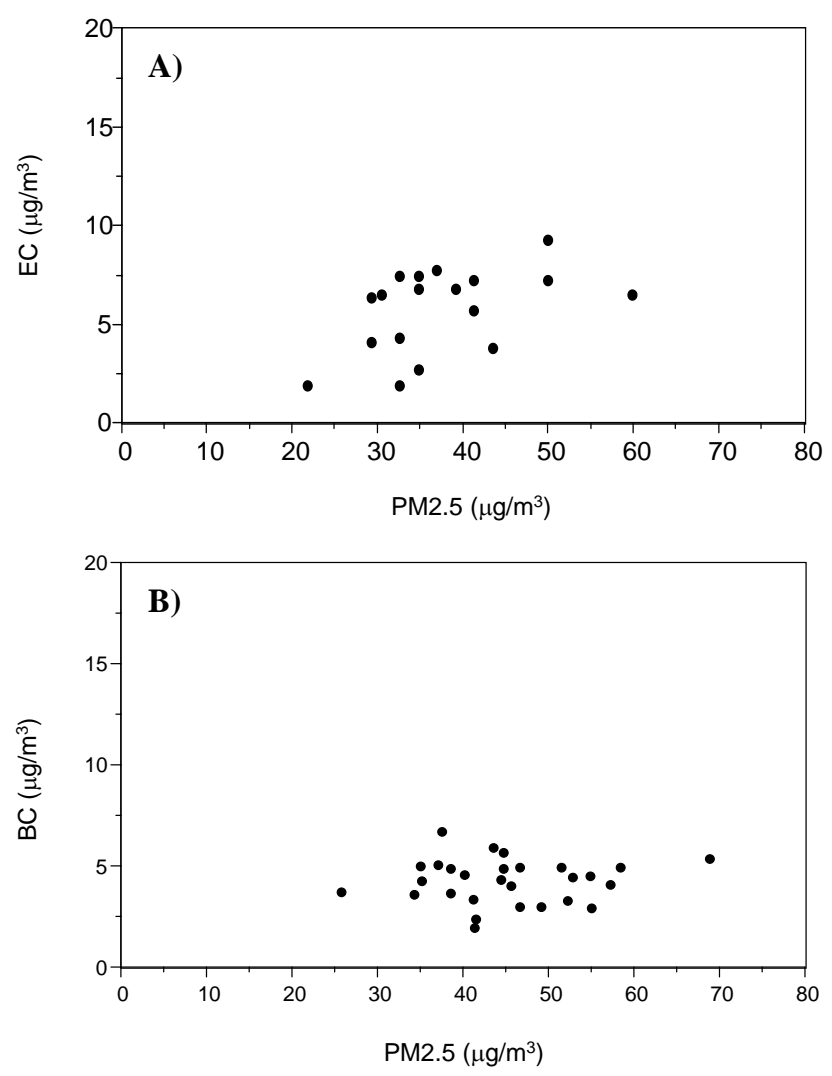

Fig. 4. (A) Elemental carbon content of $\mathrm{PM}_{2.5}$ particulate samples collected during the IMADA-AVER study, 1997 (Edgerton et al., 1999) and (B) black carbon and $\mathrm{PM}_{2.5}$ aerosol concentrations measured during the Mexico Megacity 2003 study.

as indicated by the fact that $\mathrm{NO}_{2}$ reaches a maximum before noon. At this time both ozone and PAN begin to be produced with PAN reaching a maximum earlier than ozone. Shortly after midday the boundary layer height increases leading in a reduction of $\mathrm{NO}_{2}$ atmospheric concentrations. In late afternoon PAN levels begin to drop faster than ozone. As this rapid decrease in PAN is not likely due to reaction with NO, because this would cause ozone to be lost faster than PAN, it was proposed in 1997 that this behavior might be due to heterogeneous loss of PAN on carbonaceous aerosol surfaces (Gaffney et al., 1999). It has been shown in laboratory studies that PAN can be lost on contact with soot surfaces at low ppb levels during relatively short contact times (Gaffney et al., 1998). Figure $3 \mathrm{~b}$ also includes the black carbon aerosol profiles obtained in 2003. The $\mathrm{NO}_{2}$ concentration levels correspond well with the black carbon concentrations as both black carbon and $\mathrm{NO}$, the $\mathrm{NO}_{2}$ precursor, are produced from combustion. The PAN levels in Fig. $3 b$ begin to drop after the black carbon concentrations reach their maximum supporting the suggestion of heterogeneous PAN loss. This same loss pattern has also been observed in Santiago, Chile where PAN levels have been seen to exceed 20 ppb (Rappengluck et al., 1998, 2000). This city has a large diesel bus fleet and the black carbon levels are likely to be even higher than those observed in Mexico City.

Daily average $\mathrm{PM}_{2.5}$ concentrations have been reported elsewhere for La Merced site during the AMADA-AVER campaign in 1997 (Edgerton et al., 1999; Chow et al., 2002). These fine aerosol levels ranged from $21-60 \mu \mathrm{g} / \mathrm{m}^{3}$ in 1997 with an average of $36 \mu \mathrm{g} / \mathrm{m}^{3}$. The daily average $\mathrm{PM}_{2.5}$ during the 2003 study ranged from $26-69 \mu \mathrm{g} / \mathrm{m}^{3}$ with an average of $45 \mu \mathrm{g} / \mathrm{m}^{3}$. This is not a significant difference in fine atmospheric aerosols from 1997 to 2003 . The samples collected in 1997 were also analyzed for elemental carbon content by thermal evolution analysis (Chow et al., 1993, 2001). Figure $4 \mathrm{a}$ shows the elemental carbon content of the $1997 \mathrm{PM}_{2.5}$ aerosol fraction as calculated from the previously reported results (Edgerton et al., 1999; Chow et al., 2002). The percent elemental carbon in the fine aerosol samples collected in 1997 varied from 6-23\% with an average during the campaign of $15(\sigma=5) \%$. Figure $4 \mathrm{~b}$ shows the daily average black carbon content of fine aerosols as determined from light absorption and TEOM measurements made in 2003 (Salcedo et al., 2006). The daily average percent black carbon in fine aerosols measured in 2003 ranged from 5-18\% with an average of $10(\sigma=3) \%$. This may represent a slight decrease in black/elemental carbon aerosol content in 2003, especially at higher $\mathrm{PM}_{2.5}$ concentrations. However, the thermal evolution method used in 1997 to determine elemental carbon may sometimes result in high values if corrections are not adequately made for charring of the sample during analysis (Chow et al., 2004).

The decreasing trend in PAN levels observed in Mexico City from 1997 to 2003 is similar to that observed in southern California where the maximum PAN concentrations have steadily decreased from $50-70 \mathrm{ppb}$ in the 1960 s to $3-10 \mathrm{ppb}$ in the 1990s (Grosjean, 2003). The PPN concentrations in southern California have also decreased from 5-6 ppb in the 1960 s to less than $1 \mathrm{ppb}$ in the $1990 \mathrm{~s}$. Peak ozone concentrations were about $540 \mathrm{ppb}$ in 1960 and 210 in 1997 (Grosjean, 2003; South Coast Air Quality Management District, 1995; www.aqmd.org). This trend in decreasing atmospheric oxidants reflects the increasingly stringent controls on VOC and $\mathrm{NO}_{\mathrm{x}}$ emissions in the state of California. Although the trend for both PAN and ozone in southern California is downward, the ambient levels of PAN have decreased faster than those of ozone yielding a decrease in the PAN/ozone ratio from 0.13 in the 1960s to 0.02 in 1997. Since California's emission controls have focused on reducing the most reactive VOCs thus reducing the overall photochemical reactivity of the emissions (Carter, 1994) it has been suggested that this may have resulted in a larger reduction of the PAN precursors compared to the VOCs that produce ozone but do not produce PAN (Grosjean, 2003).

As the Mexico City and Los Angeles areas have many similarities in their air pollution problems including, a high density of mobile emissions resulting in similar atmospheric 
chemistries, the Mexican government utilized a similar approach to improving the air quality in the MCMA as that used by the state of California (Molina and Molina, 2002b). This included the removal of reactive olefins from LPG (Blake and Rowland, 1995; DDF et al., 1996), re-strengthening motor vehicle emission standards with limits on the most reactive VOCs and the introduction of two-way catalytic converters in new vehicles starting with the model year 1991 and threeway catalytic converters stating with 1993 models (Molina and Molina, 2002b). Fuel-based motor vehicle emission inventories for Mexico City have subsequently estimated a decrease in $\mathrm{NO}_{\mathrm{x}}$ and hydrocarbon emissions of $26 \%$ and $39 \%$, respectively, from 1998 to 2000 (Schifter et al., 2003, 2005). Vehicle remote sensing studies made in 2000 showed that tailpipe hydrocarbon emissions (measured in pounds of $\mathrm{HC}$ per pound of fuel) were lowered to one ninth of those emitted by the 1991 fleet (Beaton et al., 1992; CAM/IMP, 2000). Atmospheric measurements have also reported a decrease in ambient hydrocarbon levels from 1992 to 1996 (Arriaga et al., 1997). It is therefore not surprising that results from the recent studies in Mexico City should yield results similar to those observed in the Los Angeles area with respect to atmospheric oxidants, particularly the PANs. However, fine atmospheric aerosols, including black carbon aerosols remain a problem in this megacity. This is primarily due to the lack of controls on diesel particulate emissions.

The presence of the highly absorbing black carbon aerosols in Mexico City leads to a reduction in solar flux of $17.6 \%$ locally (Raga et al., 2001b). The mass of these absorbing aerosols exported from this megacity into the surrounding region is estimated to be 6000 metric tons per day or 2 mega-tons per year of black carbon (Gaffney et al., 1999). Since freshly formed black carbon aerosols are hydrophobic, they are expected to be more resistant to washout and have longer lifetimes than more hygroscopic aerosols such as sulfate and nitrate (Gaffney and Marley, 2005b; Dua et al., 1999). In addition, since Mexico City is located at an altitude of $2.2 \mathrm{~km}$ above sea level these aerosols are introduced into the atmosphere at altitudes that would be considered to be in the free troposphere $300 \mathrm{~km}$ away and are therefore assumed to have longer lifetimes than aerosols released at lower altitudes (Raga et al., 2001b). The Mexico City Metropolitan Area is therefore a major source of black carbon aerosols to the surrounding regions and the release of these highly absorbing aerosols into the surrounding areas will have an impact on the radiative balance and climate on a regional scale.

\section{Conclusions and recommendations}

A comparison of results for PAN in Mexico City in 2003 with those obtained in 1997 indicate that the overall reactivity of the urban air chemistry has changed consistent with the control strategies that have been put into place in Mexico City, i.e., reduction of olefin content in LPG sources and the re- placement of motor vehicles with those that employ the use of catalytic converters to reduce the reactive VOC emissions. Although the levels of PAN are still fairly high for an urban center, PAN and ozone levels are gradually dropping in Mexico City with similar trends to that observed over a number of decades in the Los Angeles air basin (Grosjean, 2003).

The Mexico City urban air is generally transported downwind of the city on a daily basis leading to the strong diurnal cycles observed for PAN at the urban sites. It is apparent that both $\mathrm{NO}_{\mathrm{x}}$ and reactive VOC emissions in Mexico City, although still high, are being reduced. Although the reduction of reactive VOCs in the urban emissions leads to the reduction of photochemical oxidants in the MCMA basin, the lower reactivity of the VOCs will certainly lead to the production of PANs downwind of Mexico City as the emissions are transported out of the area. This may lead to regional impacts that were not explored in this study. It is recommended that measurements of PANs in the outflow regions should be undertaken to evaluate the potential impacts of ozone and PAN on ecosystems in the region.

The results for black carbon aerosol content indicate that this pollutant is not being reduced in Mexico City, consistent with no control strategies being put into place. It is clear that this and other megacities continue to be major sources of this key aerosol species on a global scale. As the lifetimes for black carbon aerosols are anticipated to be longer than that for the more hygroscopic aerosol species, the global impact of the emissions from megacities such as Mexico City must continue to be evaluated (Gaffney and Marley, 2005b). Considering the importance of black carbon aerosols in radiative balance, these major sources of absorbing aerosols cannot be ignored if we are to adequately assess their role in climate change.

Acknowledgements. The work at Argonne was supported by the U.S. Department of Energy, Office of Science, Office of Biological and Environmental Research (OBER), Atmospheric Science Program, under contract W-31-109-Eng-38. We wish to thank $\mathrm{Mr}$. Rick Petty of OBER for his continuing encouragement. We also wish to thank the scientists and researchers at CENICA and IMP and the Government of the Federal District, for their hospitality and help with the measurements during the IMADA-AVER and the MCMA-Mexico Megacity 2003 collaborative field studies.

Edited by: L. T. Molina

\section{References}

Allen, G. A., Lawrence, J., Koutrakis, P.: Field validation of a semicontinuous method for aerosol black carbon (Aethalometer) and temporal patterns of summertime hourly black carbon measurements in southwestern PA, Atmos. Environ., 33, 817-823, 1999.

Andreae, M. O. and Gelencser, A.: Black carbon or brown carbon? The nature of light-absorbing carbonaceous aerosols, Atmos. Chem. Phys., 6, 3131-3148, 2006, http://www.atmos-chem-phys.net/6/3131/2006/. 
Arriaga, J. L., Escalona, S., Cervantes, A. D., Ordúñez, R., and López, T.: Seguimiento de COV en aire urbano de la ZMCM 1992-1996, Contaminación Atmosférica, Vol. 2, edited by: Colin, L. G. and Verela, J. R., Universidad Autonoma Metropolitana-Iztapalapa, 67-98, 1997.

Babich, P., Davey, M., Allen, G., and Koutrakis, P.: Method comparisons for particulate nitrate, elemental carbon, and PM2.5 mass in seven U.S. cities, J. Air Waste Manage. Assoc., 50, 1095-1105, 2000.

Barth, M. C. and Church, A. T.: Regional and global distributions and lifetimes of sulfate aerosols from Mexico City and southeast China, J. Geophys. Res., 104, 30 231-30 239, 1999.

Beaton, S. P., Bishop, G. A., and Stedman, D. H.: Emission Characteristics of Mexico City Vehicles, J. Air Waste Manage. Assoc., 42, 1424-1429, 1992.

Blake, D. R. and Rowland, F. S.: Urban leakage of liquefied petroleum gas and its impact on Mexico City air quality, Science, 269, 953-956, 1995.

Bravo, H. A., Perrin, F. G., Sosa, R. E., and Torres, R. J.: Results of an air pollution strategy (lead reduction in gasoline) on the air quality of Mexico City, in: Proceedings of the 8th Clean Air Congress, Man and his Ecosystem, Elseiver Science Publishers, B.V. The Hague, The Netherlands, pp. 31-37, 1989.

CAM/IMP (Comisión Ambiental Metropolitana/Instituto Mexicano del Petróleo): Auditoría Integral al Programa de Verificación Vehicular, Report published by Comisión Ambiental Metropolitana and Instituto Mexicano del Petróleo, Mexico City, November 2000.

Carter, W. P. L.: Development of ozone reactivity scales for volatile organic compounds, J. Air Waste Manage. Assoc., 44, 881-889, 1994.

Chow, J. C., Watson, J. G., Pritchett, L. C., Pierson, W. R., Frazier, C. A., and Purcell, R. G.: The DRI thermal/optical reflectance carbon analysis system: Description, evaluation and applications in U.S. air quality studies, Atmos. Environ., 27A, 1185-1201, 1993.

Chow, J. C., Watson, J. G., Crow, D., Lowenthal D. H., and Merrifield, T.: Comparison of IMPROVE and NIOSH carbon measurements, Aerosol Sci. Technol., 34, 23-41, 2001.

Chow, J. C., Watson, J. G., Edgerton, S. A., and Vega, E.: Chemical composition of $\mathrm{PM}_{2.5}$ and $\mathrm{PM}_{10}$ in Mexico City during winter 1997, Sci. Total Environ., 287, 177-201, 2002.

Chow, J. C., Watson, J. G., Chen, L.-W. A., Arnott, W. P., and Moosmüller, H.: Equivalance of elemental carbon by ther$\mathrm{mal} /$ optical reflectance and transmittance with different temperature protocols, Environ. Sci. Technol., 38, 4414-4422, 2004.

Chung, S. H. and Seinfeld, J. H.: Climate response of direct radiative forcing of anthropogenic black carbon, J. Geophys. Res., 110, D11102, doi:10.1029/2004JD005441, 2005.

DDF (Departamento del Distrito Federal,Gobierno del Estado de México, Secretaría de Medio Ambiente Recursos Naturales y Pesca, and Secretaría de Salud): Programa para mejorar la calidad del aire en el Cvalle de Mèxico, 1995-2000 (PROAIRE), Mexico, 1996.

Doran, J. C., Abbott, S., Archuleta, J., Bian, X., Chow, J., Coulter, R. L., de Wekker, S. F. J., Edgerton, S., Elliott, S., Fernandez, A., Fast, J. D., Hubbe, J. M., King, C., Langley, D., Leach, J., Lee, J. T., Martin, T. J., Martinez, D., Martinez, J. L., Mercado, G., Mora, V., Mulhearn, M., Pena, J. L., Petty, R., Porch, W., Russell,
C., Salas, R., Shannon, J. D., Shaw, W. J., Sosa, G., Tellier, L., Templeman, B., Watson, J. G., White, R., Whiteman, C. D., and Wolfe, D.: The IMADA-AVER boundary layer experiment in the Mexico City area, Bull. Amer. Meteorol. Soc., 79, 2497-2508, 1998.

Dua, S. K., Hopke, P. K., and Raunemaa, T.: Hygroscopicity of Diesel Aerosols, Water Air Soil Poll., 112, 247-257, 1999.

Edgerton, S. A., Arriaga, J. L., Archuleta, J., Bian, X., Bossert, J. E., Chow, J. C., Coulter, R. L., Doran, J. C., Doskey, P. V., Elliot, S., Fast, J. D., Gaffney, J. S., Guzman, F., Hubbe, J. M., Lee, J. T., Malone, E. L., Marley, N. A., McNair, L. A., Neff, W., Ortiz, E., Petty, R., Ruiz, M., Shaw, W. J., Sosa, G., Vega, E., Watson, J. G., Whiteman, C. D., and Zhong, S.: Particulate air pollution in Mexico City: A collaborative research project, J. Air Waste Manage. Assoc., 49, 1221-1229, 1999.

Elliott, S., Blake, D. R., Rowland, F. S., Lu, R., Brown, M. J., Williams, M. D., Russell, A. G., Bossert, J. E., Streit, G. E., Santoyo, M. R., Guzman, F., Porch, W. M., McNair, L. A., Keyantash, J., Kao, C-Y. J., Turco, R. P., and Eichinger, W. E.: Ventilation of liquefied petroleum gas components from the valley of Mexico, J. Geophys. Res., 102, 21 197-21 207, 1997.

Fast, J. D. and Zhong, S.: Meteorological factors associated with inhomogeneous ozone concentrations within the Mexico City basin, J. Geophys. Res., 103, 18 927-18 946, 1998.

Finlayson-Pitts, B. J. and Pitts Jr., J. N.: Chemistry of the Upper and LowerAtmospheric, Academic Press, San Diego, California, 2000 .

Gaffney, J. S., Fajer, R., and Senum, G. I.: An improved procedure for high purity gaseous peroxyacetyl nitrate production: use of heavy lipid solvents, Atmos. Environ., 18, 215-218, 1984.

Gaffney, J. S., Marley N. A., and Prestbo, E. W.: Peroxyacyl nitrates (PANS): Their physical and chemical properties, in: Handbook of Environmental Chemistry, Volume 4/Part B (Air Pollution), edited by: Hutzinger, O., Springer-Verlag, Berlin, Germany, pp. 1-38, 1989.

Gaffney, J. S., Marley, N. A., and Prestbo, E. W.: Measurements of peroxyacetyl nitrate $(\mathrm{PAN})$ at a remote site in the southwestern United States: Tropospheric implications, Environ. Sci. Technol., 27, 1905-1910, 1993.

Gaffney, J. S., Marley, N. A., Martin, R. S., Dixon, R. W., Reyes, L. G., and Popp, C. J.: Potential air quality effects of using ethanolgasoline fuel blends: a field study in Albuquerque, New Mexico, Environ. Sci. Technol., 31, 3053-3061, 1997.

Gaffney, J. S., Bornick, R. M., Chen, Y.-H., and Marley, N. A.: Capillary gas chromatographic analysis of nitrogen dioxide and PANs with luminal chemiluminescent detection, Atmos. Environ., 32, 1145-1154, 1998.

Gaffney, J. S., Marley, N. A., Cunningham, M. M., and Doskey, P. V.: Measurements of Peroxyacyl Nitrates (PANs) in Mexico City: Implications for Megacity Air Quality Impacts on Regional Scales, Atmos. Environ., 33, 5003-5012, 1999.

Gaffney, J. S. and Marley, N. A.: Analysis of Peroxyacyl Nitrates (PANs), Organic Nitrates, Peroxides, and Peracids, Chapter 19, in: Chromatographic Analysis of the Environment, 3rd Edition, edited by: Nollett, L., Marcel Dekker/CRC Press, pp. 711-741, 2005a..

Gaffney, J. S. and Marley, N. A.: The Importance of the Chemical and Physical Properties of Aerosols in Determining Their Transport and Residence Times in the Troposphere, Chapter 14, in: 
Urban Aerosols and Their Impacts: Lessons Learned from the World Trade Center Tragedy, edited by: Gaffney, J. S. and Marley, N. A., ACS Symposium Book 919, Oxford University Press, pp. 286-300, 2005b.

Gaffney, J. S. and Marley, N. A.: A brief history of aerosol carbon analytical methods. Eighth Conference on Atmospheric Chemistry Symposium: Aerosols - Radiative Impacts and Visibility Reduction, 86th American Meteorological Society National Meeting, Atlanta, GA 2006, Proceedings Volume, Paper 1.5., 2006.

Grosjean, D.: Ambient PAN and PPN in southern California from 1960 to the SCOS97-NARSTO, Atmos. Environ., 37, S221S238, 2003

Hansen, A. D. A., Rosen, H., and Novakov, T.: Real-time measurement of the absorption coefficient of aerosol particles, Appl. Opt., 21, 3060-3062, 1982.

Hansen, A. D. A. and McMurry, P. H.: An intercomparison of measurements of aerosol elemental carbon during the 1986 Carbonaceous Species Methods Comparison Study, J. Air Waste Manage. Assoc., 40, 894-895, 1990.

Hinds, W. C.: Aerosol technology: properties, behavior and measurement of airbourne particles, John Wiley and Sons, USA, 1999.

Jacobson, M. Z.: Global direct radiative forcing due to multicomponent anthropogenic and natural aerosols, J. Geophys. Res., 106, 1551-1568, 2001.

Jacobson, M. Z.: Conrol of fossil fuel particulate black carbon and organic matter, possibly the most effective method of slowing global warming, J. Geophys. Res., 107(D19), 4410-4432, doi:10.1029/2001JD001376, 2002.

Jacobson, M. Z.: Climate response of fossil fuel and biofuel soot, accounting for soot's feedback to snow and sea ice albedo and emissivity, J. Geophys. Res.m 109, D21201, doi:10.1029/2004JD004945, 2004.

Lynn, W. R.: Megacities sweet dreams or environmental nightmares, Environ. Sci. Technol., 33, 238A-240A, 1999.

Marley, N. A., Gaffney, J. S., White, R. V., Rodriguez-Cuadra, L., Herndon, S. E., Dunlea, E., Volkamer, R. M., Molina, L. T., and Molina, M. J.: Fast gas chromatography with luminol chemiluminescence detection for the simultaneous determination of nitrogen dioxide and peroxyacetyl nitrate in the atmosphere, Rev. Sci. Instrum., 75, 4595-4605, 2004.

Marley, N. A., Gaffney, J. S., Baird, J. C., Blazer, C. A., Drayton, P. Pj., and Frederick, J. E.: The determination of scattering and absorption coefficients of size-fractionated aerosols for radiative transfer calculations, Aerosol Sci. Technol., 34, 535-549, 2001.

MARI: Mexico City Air Quality Initiative, Los Alamos National Laboratory and the Mexican Petroleum Institute, Los Alamos Report \#LA-12699, 1994.

Molina, L. T. and Molina, M. J.: Air quality impacts: Local and global concern, Chapter 1, in: Air quality in the Mexico Megacity, An integrated assessment, edited by: Molina, L. T. and Molina, M. J., Kluwer Academic, Netherlands, 2002a.
Molina, L. T. and Molina, M. J.: Cleaning the air:A comparative study, Chapter 2, in: Air quality in the Mexico Megacity, An integrated assessment, edited by: Molina, L. T. and Molina, M. J., Kluwer Academic, Netherlands, 2002b.

Raga, G. B., Baumgardner, D., Castro, T., Martìnez-Arroyo, A., and Navarro-González, R.: Mexico City air quality: a qualitative review of gas and aerosol measurements (1960-2000), Atmos. Environ., 35, 4041-4058, 2001a.

Raga, G. B., Castro, T., and Baumgardner, D.: The impact of megacity pollution on local climate and implications for the regional environment: Mexico City, Atmos. Environ., 35, 18051811, 2001b.

Ramanathan, V., Chung, C., Kim, D., Bettge, T., Buja, L., Kiel, J. T., Washington, W. M., Fu, Q., Sikka, D. R., and Wild, M.: Atmospheric brown clouds: Impacts on South Asain climate and hydrological cycle, Proc. Natl. Acad. Sci. USA, 102, 5326-5333, 2005.

Rappengluck, B., Oyola, P., Olaeta, U. I., Schmitt, R., and Fabian, P.: The evolution of photochemical smog in the metropolitan area of Santiago, Chile, Preprint Paper 3.8, 10th Conference on Air Pollution Meteorology, \& 8th Annual Meeting of the American Meteorological Society, Phoenix, AZ, pp. 86-90, 1998.

Rappengluck, B., Oyola, P., Olaeta, I., and Fabian, P.: The evolution of photochemical smog in the metropolitan area of Santiago, Chile, J. Appl. Meteorol., 39, 275-290, 2000.

Riveros, H. G., Arriaga, J. L., Tejeda, J., Julián-Sánchez, A., and Riveros-Rosas, H.: Ozone and its precursors in the atmosphere of Mexico City, J. Air Waste Manage. Assoc., 48, 866-871, 1998.

Salcedo, D., Onasch, T. B., Dzepina, K., Canagaratna, M. R. Zhang, J. Q., Huffman, A., DeCarlo, P. F., Jayne, J. T., Mortimer, P., Worsnop, D. R., Kolb, C. E., Johnson, K. S., Zuberi, B., Marr, L. C., Volkamer, R., Molina, L. T., Molina, M. J., Cardenas, B., Bernabé R. M., Márquez, C., Gaffney, J. S., Marley, N. A., Laskin, A., Shutthanandan, V., Xie, Y., Brune, W., Lesher, R., Shirley, T., and Jimenez, J. L.: Characterization of ambient aerosols in Mexico City during the MCMA-2003 campaign with Aerosol Mass Spectrometry: results from the CENICA Supersite, Atmos. Chem. Phys., 6, 925-946, 2006, http://www.atmos-chem-phys.net/6/925/2006/

Schifter, I., Dìaz, L., Múgica, V., and López-Salinas, E.: Fuel-based motor vehicle emission inventory for the metropolitan area of Mexico City, Atmos. Environ., 39, 931-940, 2005.

Schifter, I., Dìaz, L., Durán, L., Guzmán, E., Chávez, O., and López-Salinas, E.: Remote sensing study of emissions from motor vehicles in the metropolitan area of Mexico City, Environ. Sci. Technol., 37, 395-401, 2003.

South Coast Air Quality Management District: Air Quality Digest November, December, 1985.

Streit, G. E. and Guzman, F.: Mexico City air quality: Progress of an international collaborative project to define air quality management options, Atmos. Environ., 30, 723-733, 1996.

Tuazon, E. C., Winer, A. M., Pitts Jr., J. N.: Trace pollutant concentrations in a multiday smog episode in the California south coast air basin by long path length Fourier transform infrared spectroscopy, Environ. Sci. Technol., 15, 1232-1237, 1981. 